\title{
Discurso de Mariano Lebrón Saviñon, al recibir el título de Profesor Distinguido de la UNPHU.
}

Federico Loliee, escritor francés de elegante estilo, cuenta en su formidable Historia de las Literaturas comparadas, un hecho maravilloso que fascinó al mundo, deslumbrando por la luz astral de la cultura greco latina que emergía de las foscas tinieblas medievales del siglo XVI. Unos obreros -dicemientras realizaban excavaciones en Roma en un proceso de remodelación, hicieron el hallazgo de una tumba perdida allí por luengos siglos. Al levantar la tapa de la urna funeraria se presentó a la vista absorta de los curiosos un espectáculo maravilloso: yacente, como estatua carnea que el tiempo había preservado, una doncella de hermosura increible, incorrupta $y$ pura, con los brazos en cruz sobre el virgineo seno, inmóviles, como hecha de mármol celeste, ofrecía congelada en sus labios una sonrisa de dulzura inmortal.
En su frente una guirnalda de rosas marchitas apresaba unos cabellos chorreantes de oro ancestral y en su rostro parecía haberse detenido el tiempo. Era. como una vestal escondida a los ojos profanos pero preservada para un glorioso destino.

Multitudes de Europa corrieron a la contemplación del milagro. Un rumor de admiración creciente volcó su música sobre el sepulcro de la belleza que ahora surgía con la majestad de su grandor y la oración, sentida y trémula, cayó, como una lluvia de aromas, sobre la inerte hermosura estremécedora de la doncella.

Hasta que una noche, calladamente, el Papa, temiendo la resurrección de un culto infame de una nueva paganía, hizo desaparecer el cadáver para siempre. Pero no pudo acallar la admiración ni el nuevo culto que se hizo vivo 
de luz y de esperanza en el rumor de la brisa, en la canción de las alondras, en el esplendor del cielo. $Y$ se hizo estremecedor en las tempestades orquestales que acailaban las voces trovadorescas $y$ en el golpe del cincel sobre el mármol que adquiría formas mórbidas $y$ divinas como si fueran modeladas por el mismo Dios.

Era el Renacimiento que aparecía como eclosión gloriosa de un hecho histórico excepcional.

Volver de un pasado de hierro a un pasado de mármol, dejando levantado para siempre el rastrillo dei palacio feudal es uno de esos hechos de la Historia de perennal vigencia en el destino luminoso del Hombre.

$Y$ los hechos se repiten en paráfrasis magnífica. Un día, un grupo de obreros del ideal, en la antigua y altiva ciudad de Santo Domingo que señoreó su influjo por casi dos centurias sobre el área del Caribe y mantiene su orgullo no abatido sobre la recia petrez de sus gloriosos calicantos, cavando con aperos nuevos en la tierra hostil, hizo el hallazgo, y más que hallazgo el descubrimiento de otra estatua yacente: la de la dignidad, que se hizo sólida y eterna en una realidad indestructible: nuestra gloriosa Universidad Nacional. Pedro Henríquez Ureña.

Muchos de los que realizaron aquella titánica hazaña, y se creyó quijotesca, han desaparecido ya; otros se han retirado, y otros, los menos quizás, permanecen activos.

Hoy, diez y nueve años después de aquella.hazaña, nuestra
Universidad, hace un reconocimiento conmovible a diez de aquellos hombres y mujeres que lo antepusieron todo - incluyendo el sosiego- ante la realidad que fabricaban. Son diez, diez, que me disciernen el al to honor de hacerme eco de su gratitud, cosa que realizo con humildad, pero encendido por el fuego de una emoción incontenida; diez que en este acto solemne $e$ inolvidable rompen el pulido cristal de su añoranza, de sus nostalgias desgarradas, para evocar con la mente del corazón aquellos días de lucha, de sueños y esperanzas, de dudas y optimismos, cuando crear una universidad no era, como hoy, impulsos de intereses, sino verdadero Tabor de desvelos y quijotescas andanzas, y miren si es acertado o no el mote de Quijote que se nos dió, que hasta los Sancho Panza, como en la novela inmortal de Miguel de Cervantes y Saavedra, se han quijotizado. Aludo a la transformación del clásico escudero manchego cuando frente a la realidad de la muerte de su amo -quien había descendido del ensueño de la locura a la tajante realidad de la cordura - le suplicaba con lágrimas ardientes no cometer la locura de morir, sino salir de nuevo por los andurriales del mundo en busca, de Dulcinea, vueltos pastores y cantando endechas de amor entre el rebañejo turbión de los apriscos.

Diez son los que hoy - como ya otros antes - recibieron el reconfortante reconocimiento de su 
Alma Mater: Salvador Iglesias Baehr, Marina Abreu de Sallent, Demetrio Gañán Corcho, Leonte Bernard Vásquez, Luis María Sosa Vásquez y Malaquías Gil Arantegui, retirados $y a$, quienes reciben el título de Profesor Emérito; y los todavía activos: Rose Marguerite Taulé Casso, Héctor Luis Rodríguez Jimér.ez, Antonio Prats Ventos y quien les habla desde el podio honrador de este Auditorio. Si grande es el honor que me dispensa el Señor Rector y con él, el Consejo Académico, éste se acrecienta con la noble compañía de mis colegas homenajeados junto conmigo.

El Dr. Salvador Iglesias Baehr es sincero amigo, filósofo amable, al ma serena, uno de los paradigmáticos de mi país $y$ su noble trayectoria es emuladora; la Dra. Marina Abreu de Sallent es abnegada y admirable mujer, farmacéutica de las que con más vehemencia ha propugnado la jerarquización de la profesión elegida, y durante los días controversiales en los que nos afanábamos por crear nuestra UNPHU, ella era - y todos saben que no exagero - el hada buena, la valentísima estimuladora, refacción de fe y de esperanza; el Ing. Demetrio Gañán Corcho lleva en su acervo personal la gloria silente de haber dirigido con idoneidad incomparable, la erradicación del paludismo en nuestro país en lapso, que no debemos olvidar, en el que esto fue una realidad. Pero Gañán Corcho une - cosa insólita en nuestro tiempo - a su capacidad abrumadora una modestia que se diluye en un habla suave $y$ serena, $y$ un sentido profundo de la amistad.

En el Ing. Leonte Bernard Vásquez hay las fulguraciones del genio. Es, iquién lo duda?, de esos hombres buenos que inspiran cosas nobles con su sóla presencia. Es distraido y por momento se ve retozar en sus ojos un genio travieso que lo estremece. Pero ni aún así su alma noble vibra al clangor de una vanidad pueril ni tuerce su camino en la ruta de la enseñanza y el bien.

El Dr. Luis María Sosa Vásquez - aunque no es fundador de la UNPHU está ligado a astras primeras luchas- es un abogado prestigioso y honesto, cuyo acervo docente es al tamente apreciado. $Y$, por último, el Profesor Malaquías Gil Arantegui-- gran español unido a nosotros tanto por su españolía como por au amor a nuestra patria donde hundió sus raices trashumantes - es la elegancia y la fineza en los giros sonoros de su habla castellana. Ellos se han ido ya: la UNPHU los consagra como profesores eméritos en honra a sus fecundos pasos por su ámbito glorioso. Mientras ellos tiemblan en sus nuevos quehaceres heridos de nostalgias anhelosas, la UNPHU guarda sus recuerdos en cada rincón de sus aulas, en cada henda de sus muros, en cada rumor de sus perfumes.

Otros reciben el título de profesores distinguidos. El que yo haya merecido este honor junto con ellos es dádiva generosa que nunca olvidaré.

Porque ellos encarnan también la dignidad, esa dignidad bajo cuyo 
palio nació nuestra gloriosa institución docente, "hija de un pródigo esfuerzo," como hontana luminosa de cultura humanística en cuyo egregio tazón se arrebujan las deslumbrantes tradiciones patrias.

Margot Taulé, más que arquitecta de acrisolada solvencia es una verdadera forjadora de destinos y ejemplo de nuble actitud con la lustral limpidez de su vida. Héctor Luis Rodríguez - pionero de la veterinaria dominicana - enriquece también la vida con su presencia amable; y Antonio Prats Ventós, como un pequeño dios - "crea para que te parezcas a los dioses," dijo Moreno Jimenes - le ha regalado a su nueva patria dominicana un prodigio de obras admirables con sus manos taumaturgos, un regalo del bellezas.

¿No es, acaso, un regalo del cielo -aunque sea obra de mis amigos presentes en el Consejo Académico de la UNPHU - el que yo figure junto a ellos?

Yo he soñado con estos momentos estelares de la vida, pues tuve una niñez astrológica y era en el libro sideral del cielo donde buscaba, con afanosa ansiedad, la luz de mi destino. En uno de esos parpadeos luminosos pude leer entre torpor de sombras y deslumbres, la razón por la cual Unamuno, et vasco genial de "El sentimiento trágico de la vida" afirmaba que sólo es posible apreciar las perspectivas del hombre en el abismo de su propia soledad, a través del cristal deslumbrante de una lágrima.
Ahora estamos frente a una rara generación que se forja una insolente conciencia del yo, lo cual es una forma de narcisismo, un narcisismo espiritual que puede ser, en última instancia, expresión de la agonía romántica, en la que se agotan las posibilidades de creación cuando se extingue el ámbito de nuestras imágenes creadoras. Al concebir ese ámbito donde todas las posibilidades pueden refugiarse, desterramos el ángel y conocemos la soledad, la radical soledad que es nuestra vida.

Actos como este son necesarios y reconfortantes en la hora en que vivimos. El mundo hoy se nos antoja hostil y extraño.

Todo se transforma con una celeridad desejeante; el hombre se anonada ante la perspectiva de su autodestrucción a la que se entrega inexorablemente con una insensatez que espanta. Se escucha, como en un trágico ritual de colosales monstruos, el raudo tableteo de la muerte. Vivimos con una lenta mentalidad en continua aceleración. La vida se nos impone avasallante en un caos insolente de convencionalismo fabricados, todo porque, con insensato orgullo, imbuidos de nuestra superioridad, prescindimos de Dios por la creencia falaz de que no lo necesitamos.

Como dice muy bien Patrick Ravignat:

"El drama de nuestra época reside en que habiéndose transformado, trastornado nuestro medio por los progresos técnicos, no supimos o no qusimos imprimir el mismo 
impulso, el mismo impetu, a nuestra conciencia."

$Y$ más que eso - agrego yo hemos querido borrar del panorama de nuestra vida la conciencia."

Grande cosa es, entonces, que nuestra Univérsidad, que lleva el nombre de nuestro primer humanista, surja como un bastión del humanismo bajo el aula caudal de una insposiciôn de valores incorruptibles.

El hombre es la sustancia principal de la cultura en su egregio sitial ante una naturaleza que se le antoja absurda. Pero ies que existe la naturaleza sin la visión del hombre? ¿Y Dios? ¿Qué sería de El y de su Divina Omnipotencia si yo dejara de ser? ¿No es, acaso, la Ciencia, con sus omnímodas conquistas, expresión de mi propio escepticismo y airosa revelación de mi duda? ¿No es, por cierto, el sentir científico reiteración de superaciones y desmentidos?

La naturaleza - mi naturaleza, mi orbe de sueños y esperanzas, el mundo palpable de mis creaciones - tiene un límite ideal de perspectivas y maravillas que está más allá de lo asible y objetable, más allá del entrañable mundo de mis limitaciones.

Soy poeta del verso y de la vida que reconstruyo mundos donde resarcirme de las angustias de un vivir deleznable en continuas agonías. $Y$ es mi imaginación un dios que puede volver a crear lo que la Ciencia, en el campo de la causalidad, ha destruido.

Soy un pequeño dios en búsqueda de conquistas espectaculares en la tierra y en el cosmo y he vencido todo cálculo en las posibilidades destructivas; pero no puedo, como afirma Zenón de Elea - bañarme dos veces en el mismo río.

Pero, como dice Heráclito, el baño en el río es baño de olas mortales; flotamos en sus devenires en una constante mutación. Ya no es posible la soberbia, ni la ardiente vanidad, ni la rojiza petulancia altiva. En el mundo cenital de nuestros sueños, cón mortecina luz, en la caverna calíginosa, la muerte nos acecha, inmutable, tensa, como adorable deidad. $Y$ nos recuerda, como el salmista, que fue pecado nuestro anhelar $y$ que tesoros $y$ vanidades se quedan a la puerta del sepulcro. Se habla de la muerte y se anhela eternidad. $Y$ en el ruido ensordecedor de este mundo perturbado se escucha, como una angustia colosal, la voz de Miguel de Unamuno, pidiendo eternidad. $Y$ ella será nuestra, porque si es destructible la carnea naturaleza, en la tétrica majestad de su materia putrescente, nos queda el alma que se hinche de adorables atributos para alcanzar la eternidad soñada en esta finitud de nuestra vida..

Estamos frente a la fuente murmuradora y vagabunda; sus aguas turbias nos aterran, pero ese terror se disipa cuando escuchamos el refrescante tremar de sus salterios o apagamos la sed, sed infinita de sequedad del alma, en la hora canicular de nuestra angustia.

Ya no es posible tener terror, ni estremecimientos, como las 
convulsiones que cracterizan los montes. Porque estamos más allá del mito y del misterio.

El hombre recio - y recios fuimos los que en un momento conflictivo de la Historia creamos la UNPHU - debe sonreir cuando aparece la tormenta; quedarse quieto, con una terca raya de desdén en la frente, ante el retumbo repetido del trueno que se asoma primero, cual ignea mueca, en la sierpe de luz del relámpago. $Y$ huir hacia la cima nunca hacia el abismo, cuando escuche rodar la ronca voz de las tempestades. Cuando llegue a la cúspide en la búsqueda de su propia soledad arcana dirá, como el carnero perseguido que hizo piruetas alpinas a través de las escarpaduras montanales, cuando atisbó desde lo al to la muchachada que lo hostilizó con la pedrea: " iPero! iqué pequeños son!".

Así, en la cumbre, levantará su frente, y si debe morir víctima de la cólera ignota, que lo haga como Brand, sepultado en el derrumbe ventisqueral de su imponente catedral de hielo, rebelde y pugnaz, como un nuevo Prometeo encadenado.

Señores:

Hoy es un día feliz para un grupo de egregios alfareros del saber. Entre ellos -egregios todos, en el buen decir del vocablo, libre de toda semántica estragada - me yergo yo, si mas humilde, pareable con ellos en el ímpetu vehemencial $y$ en el sentido verdadero de la palabra dignidad, bajo cuya pérgola, henchida de ofertas sazonadas. erijimos esta Universidad que hoy nos vuelve con inesperado honor el premio a nuestro esfuerzo.

Yo hablo por ellos y por ellos expreso cómo se desborda catarata de agradecimiento - la dicha que nos embarga.

Ellos son dignos de este honor y yo también: porque hoy recojo, estremecido, en este simple pliego que el Rector Jaime Viñas Román puso en mis manos como un regalo al mérito el premio a noches de angustias, bajo las sombras de dudas lascerantes, y a este amor, este amor más mío que mi propio corazón que entre tributos de ensueños y trazos de realidades es, para esa eternidad que añoro, el himno prodigioso de una existencia que quiso ser fecunda.

Yo, como en el proverbio árabe, me he hecho digno de ser hombre: tengo hijos, sembré árboles, publiqué libros. Pero escancié, también, en ánfora de oro, la divina portación de la amistad Casi puedo morir. 